\title{
Observations of the Effects of Different Chemical Blowing Agents on the Degradation of Poly(Lactic Acid) Foams in Simulated Soil
}

\author{
Matheus V. G. Zimmermann, Vanessa C. Brambilla, Rosmary N. Brandalise, Ademir J. Zattera* \\ Laboratory of Polymers - LPOL, Center for Exact Sciences and Technology-CCET, \\ University of Caxias do Sul - UCS, Rua Francisco Getúlio Vargas, 1130, \\ CEP 95070-560, Caxias do Sul, RS, Brazil
}

Received: September 8, 2012; Revised: April 26, 2013

\begin{abstract}
This work examined the influence of different chemical blowing agents (CBA), one endothermic and one exothermic, at the same concentration ( $2 \%$ by mass), on poly(acid lactic), PLA foams. The CBA was incorporated into the PLA in a single-screw extruder, and the foams were expanded by heating in an electric oven under free pressure conditions. Foam degradation in a simulated soil was performed according to the ASTM G160-03 standard. Changes in the physical-chemical, morphological and mechanical properties were used to evaluate the degradation. The results indicated that the different chemical blowing agents led to different mechanical and morphological properties for the foams, which resulted from the nature and decomposition rate of the blowing agents. Cells in the foams accelerated the degradation since they facilitated the infiltration of water toward the interior of the polymer and triggered the degradation process by hydrolysis.
\end{abstract}

Keywords: PLA, chemical blowing agents, polymer foams, degradation

\section{Introduction}

Polymeric foams are two-phase systems that consist of a solid polymeric phase and a gas phase. The gaseous phase is generated during processing and distributed in voids that are called cells. Open cells are interconnected, and closed cells are isolated or independent of one another ${ }^{1}$. Cells reduce the density, improve the thermal, acoustic insulating characteristics and enhance the dampening properties of foams, thereby enabling the use of these materials in food packaging and protection applications ${ }^{2}$.

Polymeric foams are produced by deploying blowing agents that form cells in the polymer matrix. Blowing agents can be physical, such as low boiling point gases or liquids, or chemical, which are substances that decompose when heated releasing volatile gases such as carbon dioxide $\left(\mathrm{CO}_{2}\right)$ and nitrogen $\left(\mathrm{N}_{2}\right)$. The choice of the chemical blowing agent depends on the decomposition temperatures of the blowing agent, the polymer melt temperature and of the desired properties of the foam. The morphology and physical features of foam depend on the polymer matrix and the blowing agent utilized in processing ${ }^{1,3,4}$.

Polymeric foams are difficult to transport and recycle because of their low densities and bulky volumes. Gautam et al. (2007) studied the biological degradation of expanded polystyrene (EPS) and reported that EPS does not undergo short-term biodegradation in the presence of fungi and microorganisms and requires many years to decompose ${ }^{5}$. Biodegradable packaging composed of poly(lactic acid) (PLA) foam shows promise as an alternative, with a lower environmental impact than conventional EPS packaging.

*e-mail: ajzatter@ucs.br
PLA is an aliphatic, biodegradable compostable polyester that is synthesized from lactic acid, which can be obtained from renewable sources such as corn, potatoes, sugar beets and sugar cane ${ }^{6-8}$. In the environment, the overall degradation time of the PLA ranges from six months to two years and depends on the condition that the PLA is exposed. The degradation of PLA occurs at a two-step process. First, water penetrates in the PLA and hydrolyzes the ester groups. Hydrolysis attacks the amorphous segments of the polymer, reducing the chains to smaller, more soluble fragments with lower mass. Second, enzymes attack, metabolize the fragments and decompose the polymeric material ${ }^{8,9}$.

The mechanical properties of PLA are similar to those of conventional polymers such as polystyrene (PS) and polypropylene (PP). Most conventional polymer processing techniques, such as extrusion and injection, can be used for PLA ${ }^{10}$

This work focuses on using two blowing agents to form PLA foams. The degradation of the foams in simulated soil is evaluated by comparing their morphological, chemical, thermal and mechanical properties before and after exposure.

\section{Material and Methods}

\subsection{Materials}

The poly(lactic acid) grade PLA CP 5001 used in this study was manufactured and obtained from Iraplast Indústria e Comércio Ltda (Cereplast Inc). The exothermic blowing agent (EXO) was a grade CS4M azodicarbonamide with zinc oxide activation manufactured by Bayer S.A. The bicomponent endothermic blowing agent (ENDO) was 
composed of sodium bicarbonate and citric acid (1:1) and manufactured by Multicolor Indústria e Comércio de Pigmentos Ltda.

\subsection{Sample preparation}

Samples of PLA were processed with $2 \%$ (by mass) of exothermic blowing agent (E-PLA/EXO) and endothermic bicomponent blowing agent (E-PLA/ENDO) in an SEIBT model ES35 L/D29 single screw extruder. Extrusion processing was performed at low temperatures $(120,130$ and $140^{\circ} \mathrm{C}$ ) in order to avoid promoting the decomposition of the blowing agents. The mixtures were milled in a MARCONI model MA 580 knife mill with an $\varnothing 6 \mathrm{~mm}$ side sieve. The milled materials were thermally pressed in a SCHULZ model PHS $15 \mathrm{~T}$ heated press at $115^{\circ} \mathrm{C}$ with 5 tons of pressure for 10 minutes. A mold was used to obtain preform plates with $3 \mathrm{~mm}$ thick. The foams were expanded without pressure in an electric oven at $190^{\circ} \mathrm{C}$ for 10 minutes. Finally, the expanded plates were cut into specimens for physical and mechanical characterization.

\subsection{Degradation test}

The simulated soil employed for the degradation test was prepared in accordance with the ASTM G160-03 standard from a mixture of equal parts of low-clay content fertile soil, 40 mesh beach sand and horse manure. After mixing, the soil was allowed to mature for three months, and its temperature and humidity were monitored daily.

\subsection{Characterization of samples}

The E-PLA/EXO and E-PLA/ENDO samples were characterized after 0, 30, 60 and 90 days of exposure in the simulated soil, according to the requirements of the ASTM G160-03 Standard.

The apparent density of the samples was calculated by the ratio of the sample mass $(\mathrm{g})$ and volume $\left(\mathrm{cm}^{3}\right)$. In keeping with ASTM D1622-08, five replicate measurements at different locations in the expanded plate were made for each sample.

The mechanical testing by flexural tests was performed according to ASTM D790-10 at a flexural speed of $1.5 \mathrm{~mm} . \mathrm{min}^{-1}$, using an EMIC DL 3000 testing machine.

Studies on the morphology of the E-PLA/EXO and E-PLA/ENDO samples were carried out using a SHIMADZU Superscan SS-550 scanning electronic microscope (SEM) with carbon coated. For the evaluation of the size and number of the cells, three micrographs at different locations in the expanded plate were used for each sample.

Chemical properties were assessed by Fourier transform infrared spectroscopy (FTIR) in a THERMO SCIENTIFIC model NICOLET iS10 instrument using KBr tablets. The samples were scanned in the region of $4000-400 \mathrm{~cm}^{-1}$ at a resolution of $4 \mathrm{~cm}^{-1}$.

Thermal properties were evaluated using differential scanning calorimetry (DSC) in a SHIMADZU model DSC-60 instrument at a heating rate of $10{ }^{\circ} \mathrm{C} \cdot \mathrm{min}^{-1}$ and scanned from 0 to $200{ }^{\circ} \mathrm{C}$ with a 3-minute isotherm.

The glass transition $\left(\mathrm{T}_{\mathrm{g}}\right)$, cold crystallization $\left(\mathrm{T}_{\mathrm{cc}}\right)$ and crystalline melting $\left(\mathrm{T}_{\mathrm{m}}\right)$ temperatures were determined. The crystallinity index $\left(\mathrm{X}_{\mathrm{c}}\right)$ was calculated from the first heating run of DSC thermogram, and it was calculated according to Equation 1:

$$
X c(\%)=\frac{\Delta H m}{\Delta H o} \times 100
$$

where $\Delta H m$ is the melting enthalpy of the sample $(\mathrm{J} / \mathrm{g})$ and $\Delta H o$ is the melting enthalpy for $100 \%$ crystalline PLA, which corresponds to $93.6 \mathrm{~J} / \mathrm{g}^{[11]}$.

The cold crystallization time - $t c c$, (min) was calculated according to Equation 2:

$t c c=\frac{T s-T e}{\beta o}$

where $T s$ is the start crystallization temperature $\left({ }^{\circ} \mathrm{C}\right), T e$ the end crystallization temperature $\left({ }^{\circ} \mathrm{C}\right)$ and $\beta o$ is the heating/ cooling rate $\left(10^{\circ} \mathrm{C} \cdot \mathrm{min}^{-1}\right)^{[12]}$.

\section{Results and Discussion}

\subsection{Physical properties}

The apparent density is a parameter that defines the ratio between the solid and gas components of a foam. It is a crucial parameter that influences the mechanical, physical and electrical foam properties. The apparent density of the samples are: PLA $\left(1.26 \pm 0.10 \mathrm{~g} . \mathrm{cm}^{-3}\right)$ e-PLA/ENDO $\left(0.50 \pm 0.04\right.$ g.cm $\left.{ }^{-3}\right)$ and E-PLA/EXO $\left(0.44 \pm 0.02\right.$ g.cm $\left.{ }^{-3}\right)$.

The density of the neat polymer was in agreement with the value found in the literature $\left(1.26 \mathrm{~g} \cdot \mathrm{cm}^{-3}\right)^{[13]}$. For the foams, the lowest density was obtained for the E-PLA/EXO sample (65\% reduction), while the reduction was $60 \%$ for the E-PLA/ENDO sample. However, the apparent density is an average property because the density can vary from the surface to the core of a sample and vary with the cell size. Both samples exhibited rigid structural foam features with reduced bulk density at the core. Closed cells near the surface were coated with a thin layer of polymer (skin). These foams combined thermal/acoustic insulation properties with mechanical strength ${ }^{1}$.

\subsection{Foam morphology}

The morphology of foam is an important parameter because it influences many mechanical properties that depend on the organization/distribution/dimension of the cells ${ }^{1,14}$. Figure 1 illustrates the morphology of E-PLA/ENDO and E-PLA/EXO samples, after exposure to the simulated soil.

Figures 1a and 1e can be analyzed to compare the variations in the morphology and the numbers and sizes of the cells obtained with the two blowing agents. The cells in the E-PLA/EXO sample were smaller, between 141 and $463 \mu \mathrm{m}$, with an average of $289 \pm 89 \mu \mathrm{m}$. The cell concentration per unit area was higher $\left(39 \pm 7\right.$ cells $\left./ 2.5 \mathrm{~mm}^{2}\right)$ in the E-PLA/EXO sample than in the E-PLA/ENDO sample, where the cells were between 250 and $831 \mu \mathrm{m}$ with an average of $432 \pm 210 \mu \mathrm{m}$, and the number of cells per area was relatively low $\left(17 \pm 6\right.$ cells $\left./ 2.5 \mathrm{~mm}^{2}\right)$.

The degree of heterogeneity of the cells was characterized by the ratio between the numbers of larger and smaller 


\section{E-PLA/ENDO}
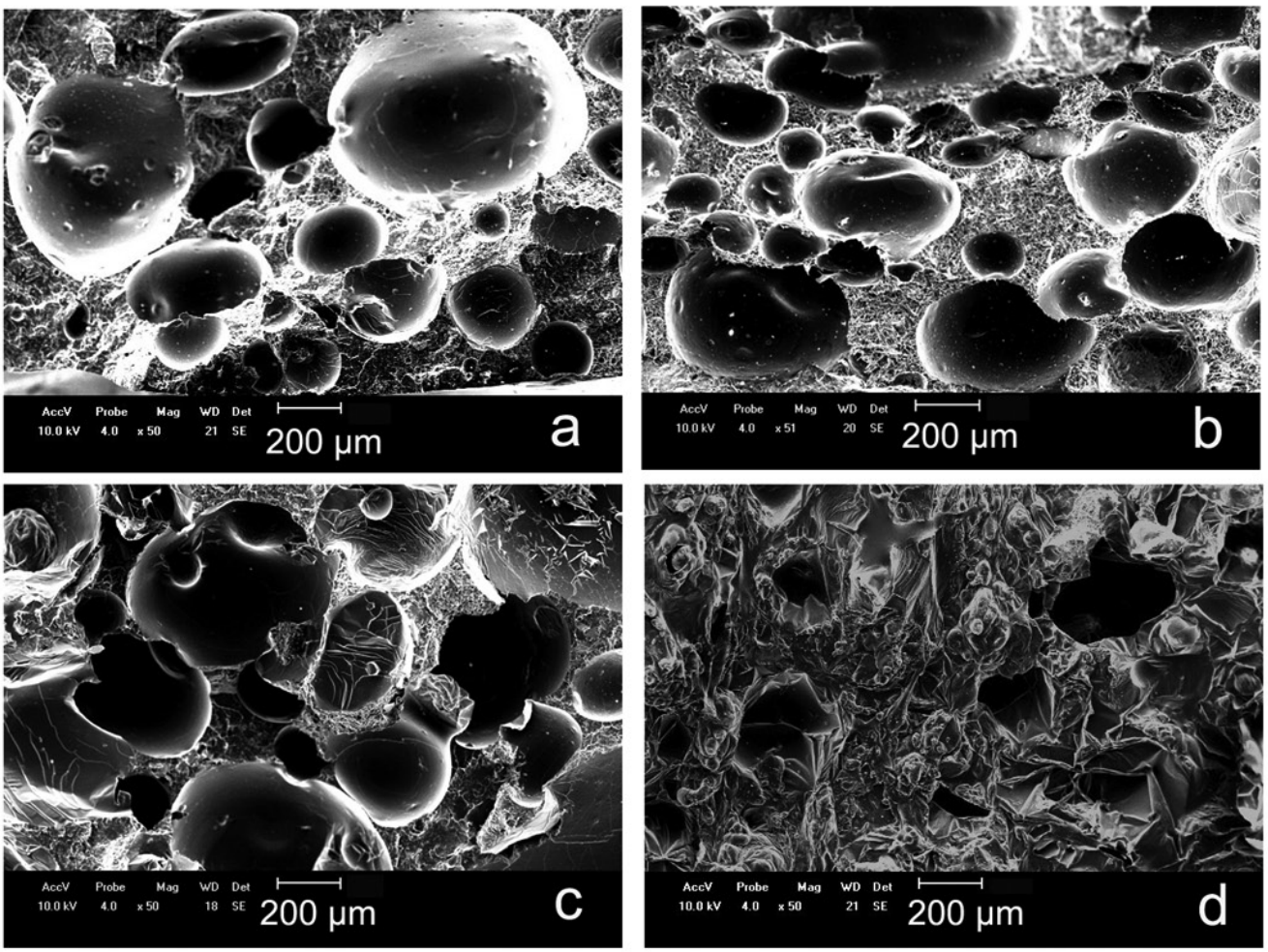

\section{E-PLA/EXO}
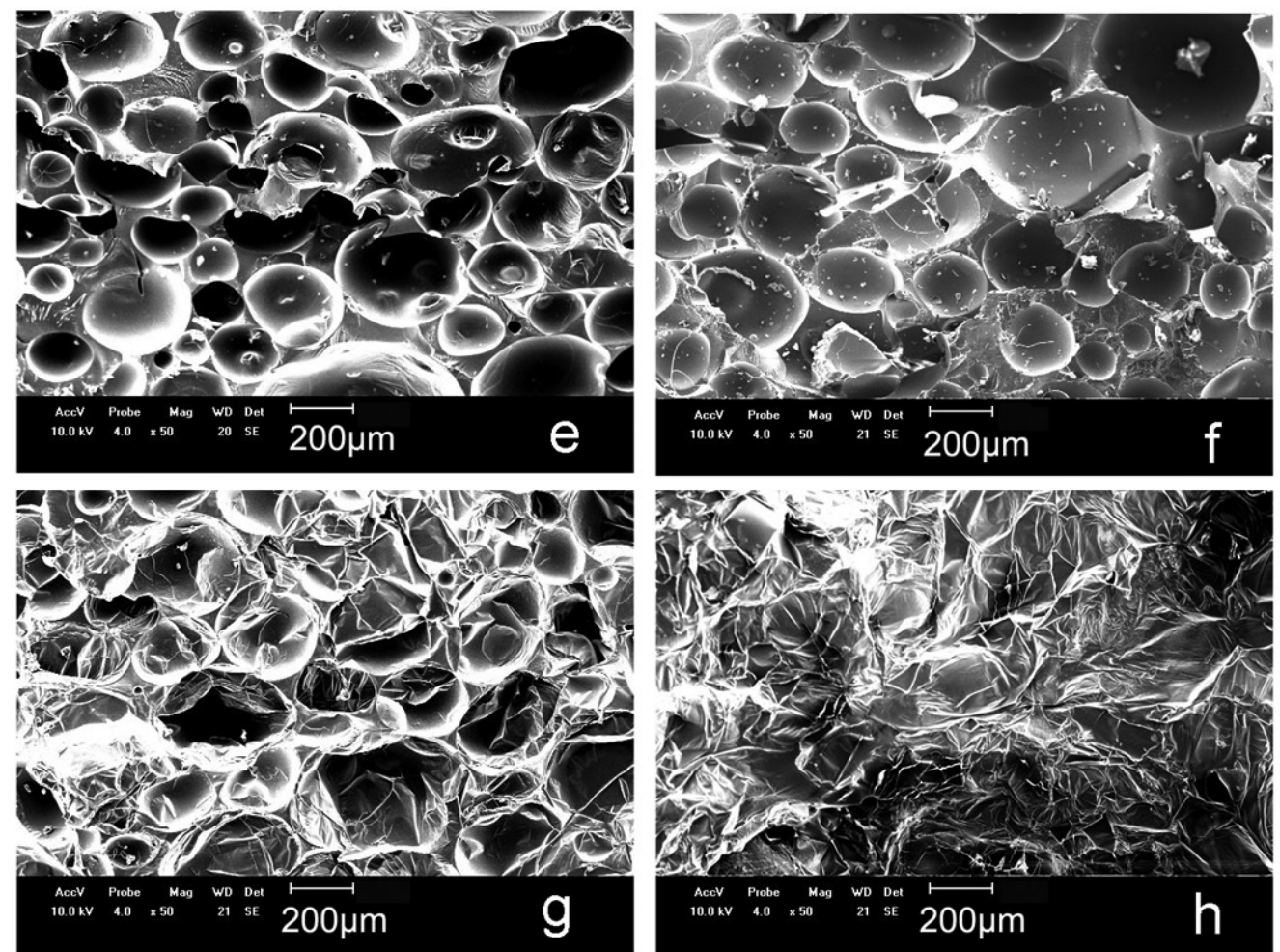

Figure 1. SEM micrograph of an E-PLA/ENDO sample after (a) 0, (b) 30, (c) 60 and (d) 90 days of exposure in the degradation test and E-PLA/EXO after (e) 0, (f) 30, (g) 60 and (h) 90 days of exposure in the degradation test. 
cells $\mathrm{s}^{15}$. As a result of the processing methodology and the absence of cross linking agents, the E-PLA/EXO and E-PLA/ENDO samples had high degrees of heterogeneity, which was consistent with the amplitude and large standard deviations from the average cell sizes.

Solid residues resulting from the decomposition of the blowing agent can act as nucleation centers and yield more uniform, better dispersed cell structures in the polymer matrix since they promote cell growth. The exothermic blowing agent caused the formation of more homogenous, smaller cell structures relative to the endothermic blowing agent. This observation can be attributed to the higher decomposition rate of exothermic blowing agent and the fact that zinc oxide likely acted as a nucleating agent during the course of expansion ${ }^{14}$.

The endothermic blowing agent has a slower decomposition rate than the endothermic blowing agent and decomposes to form water, which also acts as a blowing agent for cell formation. The gases generated by the decomposition of the blowing agent and the evaporation of water tend to penetrate into developing cells instead of forming new cells, which leads to the formation of foams with a smaller number of larger cells than the cells formed in foams produced with exothermic blowing agents ${ }^{14}$.

During exposure to the simulated soil, changes in the surfaces and morphologies of the samples were indicative of degradation ${ }^{16}$. Both samples showed gradual structure deformation such as cell failure and collapse.

Voids within the polymer matrix caused by the expansion process and cell deformation during the degradation process permit the gradual infiltration of water, which facilitates PLA degradation by hydrolysis. Pushpadass et al. (2010) studied the biodegradation of starch foams with polystyrene and two blowing agents, azodicarbonamide and citric acid. They reported that the blowing agent influenced the foam morphology and degradation. When citric acid was used as a blowing agent, the cells were larger, and the onset of biodegradation was earlier ${ }^{17}$.

\subsection{Visual features}

The evaluation of polymer degradation can be assessed by macroscopic changes in appearance, such as surface roughness, crack and void formation, color changes and microorganism colonization on the polymer surface ${ }^{18}$.

Figure 2 shows the visual features of the expanded test specimens after 90 days of exposure to simulated soil, where the arrow indicates the portion buried in the soil.

The color change from light tan to white was observed in the area exposed to the soil where decomposition occurred. Fukushima et al. (2009) attributed the formation of a white phase during degradation to the change in the refraction index resulting from the absorption of water and/or the presence of hydrolysis products ${ }^{19}$.

\subsection{Mechanical properties - flexural properties}

Figure 3 illustrates the data for the mechanical properties of the flexural strength and flexural modulus of elasticity, respectively, as functions of the exposure time in simulated soil.

The E-PLA/ENDO sample exhibited superior flexural strength $(26.7 \pm 6.4 \mathrm{MPa})$ relative to the E-PLA/EXO sample $(3.2 \pm 0.9 \mathrm{MPa})$. This superior flexural strength can be attributed to the differences in cell morphologies obtained with the different blowing agents. The larger number of cells in the E-PLA/EXO sample caused the formation of a smaller wall at the cell contour and more voids, which could have made the structure more fragile and susceptible to fracture.

The gradual reduction in the mechanical properties such as flexural strength and flexural modulus of elasticity was observed when the expanded samples were exposed to the simulated soil. These observations indicated that the degradation processes caused scission of the polymer

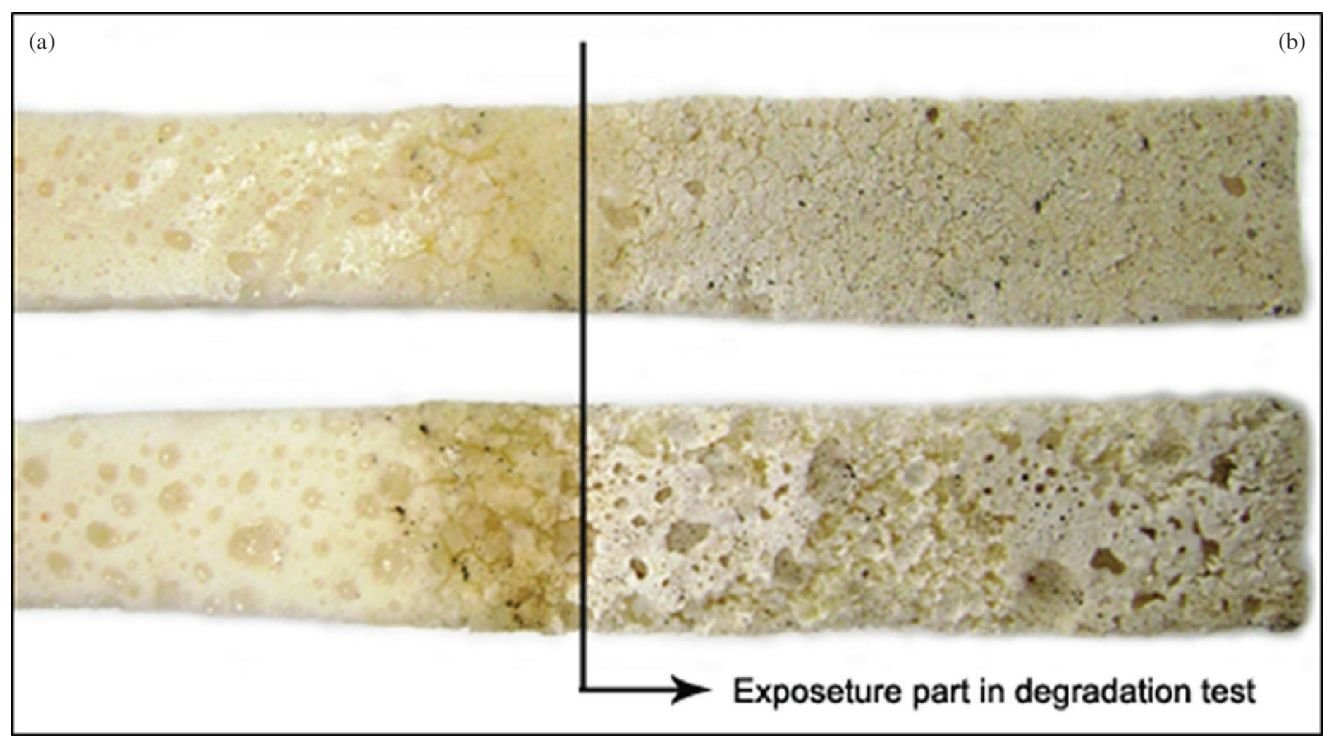

Figure 2. Photographic record of expanded test specimens of (a) E-PLA/EXO; and (b) E-PLA/ENDO after 90 days of exposure to simulated soil. 
chains and cell collapse, which decreased the mechanical properties. The reduction in the flexural modulus of elasticity after soil exposure further suggests that water infiltrated the polymer molecular structure, acted as a plasticizer and reduced the toughness properties.

\subsection{FTIR}

Figure 4 shows the spectra of E-PLA/EXO and E-PLA/ ENDO samples as a function of the exposure time in simulated soil.

The FTIR spectra contained three bands attributed to the vibration of the C-CO-O-C group, which were consistent with PLA results from the literature. The PLA characteristic bands were 2995-2946 $\mathrm{cm}^{-1}$ (the $\mathrm{C}-\mathrm{CH}_{3}$ groups), $1758 \mathrm{~cm}^{-1}$ (the carbonyl $(\mathrm{C}=\mathrm{O})$ groups), $1454 \mathrm{~cm}^{-1}$ (the $\mathrm{CH}\left(\mathrm{CH}_{3}\right)$ groups), and $1184 \mathrm{~cm}^{-1}$ (the $\mathrm{O}-\mathrm{C}-\mathrm{O}$ groups) as well as three peaks at 1129,1089 and $1044 \mathrm{~cm}^{-1}$ related to the C-C-O groups $^{20,21}$.

The exothermic blowing agent caused a band at $1613 \mathrm{~cm}^{-1}$ in the E-PLA/EXO sample that was related to the AZO $(-\mathrm{N}=\mathrm{N}-)$ compound present in the blowing agent. During the decomposition of the bicomponent endothermic blowing agent, gases such as $\mathrm{CO}_{2}$, water and sodium citrate
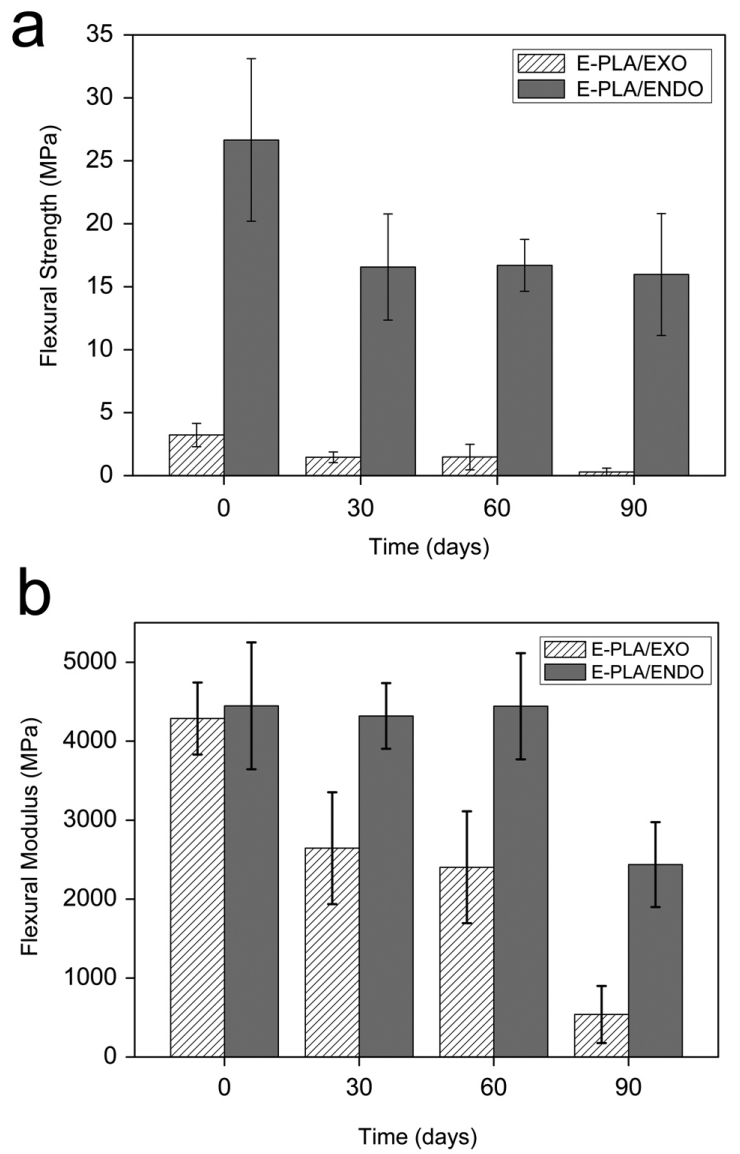

Figure 3. Flexural strength (a) and flexural modulus (b) of E-PLA/ EXO and E-PLA/ENDO samples after 0, 30, 60 and 90 days in simulated soil. were released. The appearance of the band at $1592 \mathrm{~cm}^{-1} \mathrm{can}$ be associated with the sodium citrate $\mathrm{C}=\mathrm{O}$ group $^{3}$.

Following the soil degradation test, the intensity of the main PLA characteristic bands increased, especially in the E-PLA/ENDO sample. The intensity of the $3500 \mathrm{~cm}^{-1}$ band (associated with the $\mathrm{OH}$ group) increased with exposure to simulated soil, which indicated the presence of moisture in the sample. The higher water content in the polymer could be attributed to the environment of the sample and the onset of hydrolysis, which was consistent with the evidence of infiltration of water towards the interior of the polymer. Changes and increases in the strength of the bands related to the $\mathrm{C}=\mathrm{O}$; O-C-O and $\mathrm{C}-\mathrm{C}-\mathrm{O}$ groups were observed. These changes were caused by the scission of the PLA links resulting from hydrolysis after the soil degradation test.

\subsection{Exploratory Differential Calorimetry - DSC}

Figure 5 presents the DSC thermograms for PLA, E-PLA/ENDO and E-PLA/EXO.

Three main transition temperatures were observed during the heating step of the thermograms. The glass transition temperature ( $\mathrm{Tg}$ ) was observed between 56 and
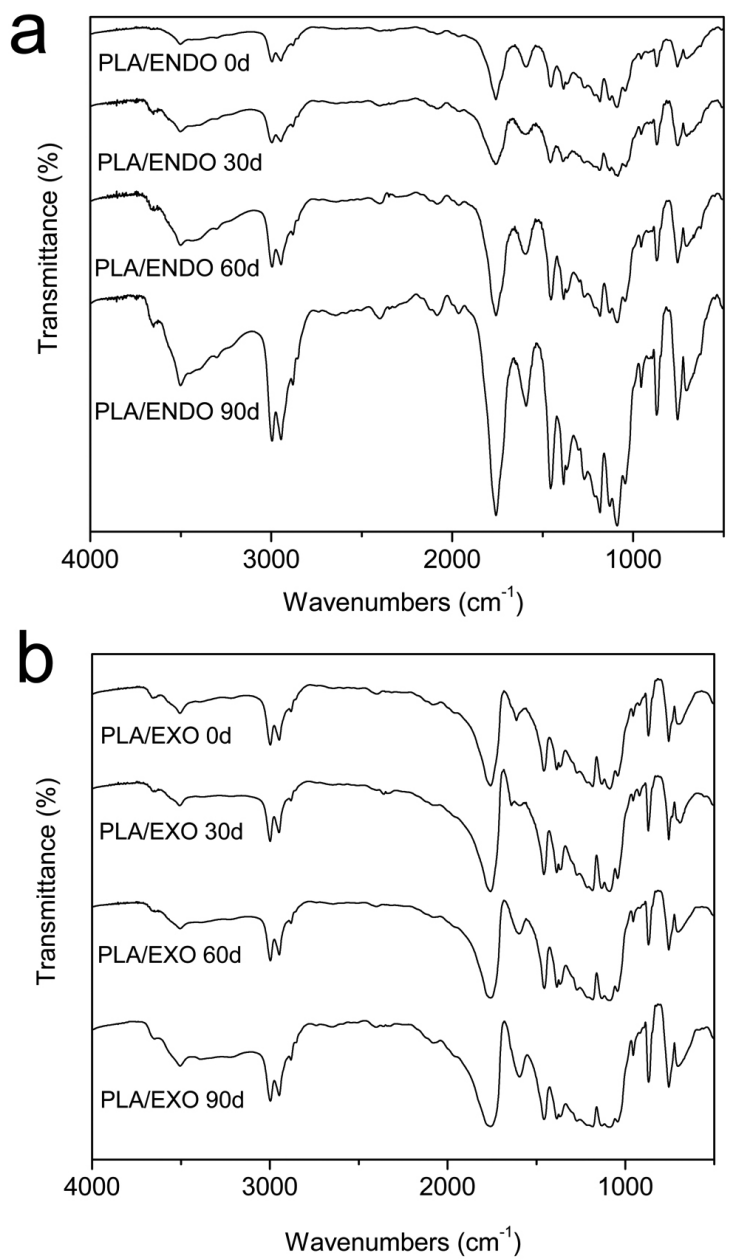

Figure 4. FTIR spectra of (a) E-PLA/ENDO and (b) E-PLA/EXO as a function of the exposure time in simulated soil. 


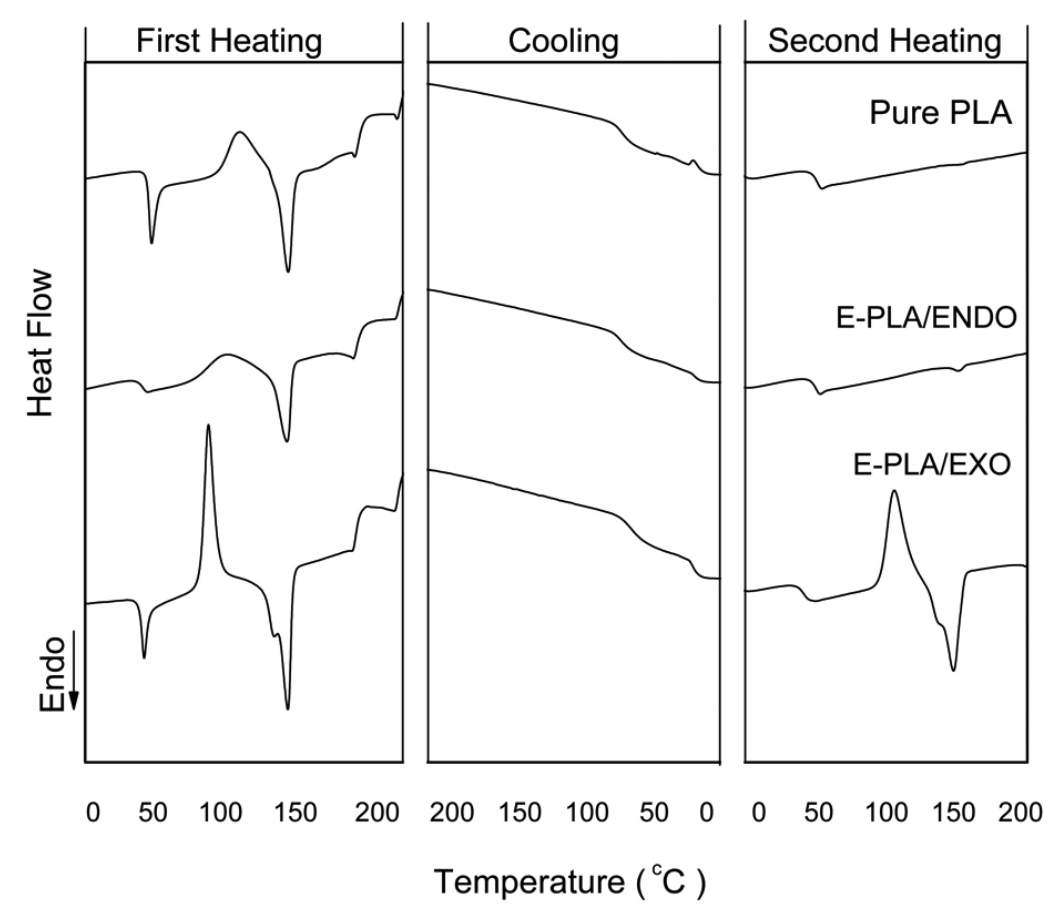

Figure 5. DSC curves of PLA, E-PLA/EXO and E-PLA/ENDO.

$60{ }^{\circ} \mathrm{C}$, the cold crystallization temperature (Tcc) was in the range between 100 and $123^{\circ} \mathrm{C}$, and an endothermic peak, related to the crystalline melting temperature (Tm), appeared at $154^{\circ} \mathrm{C}$. The exothermic peak in Figure 5 indicated that the PLA did not crystallize during the cooling step at this rate, but rather during the heating step. Qin et al. (2011) attributed the exothermic peak to a cold crystallization rate called Tcc, where the polymer gains heat with no change in phase, reaching its energy limit during its $\mathrm{Tg}$. With the increase in temperature, this energy is released with reorganization of its structure up to the point when an endothermic peak occurs, which is caused by the polymer phase (melting) ${ }^{22}$.

In the thermogram, the neat PLA and the E-PLA/ENDO samples did not display its thermal history during the second heating step, while the E-PLA/EXO sample showed all three characteristic temperatures. This result could be associated with alterations of the PLA crystallization kinetics associated with chemical interactions between the polymer, the azodicarbonamide and the zinc oxide, which acted as nucleating agent and facilitated crystallization during the second heating step.

The crystallization time and the crystallinity index of the samples after the processing are listed in Table 1.

As mentioned above, the residues of the blowing agent decomposition nucleate the formation of foam cells while influencing PLA crystallization. The peak intensity and the cold crystallization time suggest that these residues reduced the cold crystallization time, mainly in the E-PLA/EXO sample that contains solid $\mathrm{ZnO}$ particles as well as residues of decomposed azodicarbonamide. The higher Xc, in addition to the lower crystallization time, indicated that the E-PLA/EXO sample tended to form smaller crystallites than the E-PLA/ENDO sample, and the size of these crystallites had a direct influence on the mechanical properties and the PLA degradation process.

Crystallinity can be defined as an index that evaluates the higher or lower order in the three-dimensional arrangement of atomic or molecular groups. The crystallinity index of foam is related to the polymer composition, chemical structure, molecular mass and temperatures during preparation and/or processing. Higher or lower crystallinity can influence degradation processes. In broad terms, higher polymer crystallinity correlates with greater resistance to hydrolysis and oxidation degradation processes ${ }^{23}$.

Table 2 lists the results for the DSC thermal analysis for the PLA, E-PLA/EXO and E-PLA/ENDO samples during exposure in simulated soil.

No change in Tg was observed for the E-PLA/ENDO samples, while Tg for neat PLA and E-PLA/EXO decreased after exposure to simulated soil for 90 days. For all samples, Tcc decreased during the degradation process. This reduction can be associated with the formation of lactic acid oligomers resulting from chain scission during the hydrolysis and degradation of amorphous portions of the polymer, which lead to greater mobility and relaxation of the polymer chains. Chains with lower molecular mass crystallize more easily and have lower crystallization temperatures ${ }^{19}$.

The increase in crystallinity of the neat PLA after the simulated soil degradation test is associated with the fact that semi-crystalline polymers undergo preferential degradative attack in their amorphous regions, which are more susceptible to the penetration of water and oxygen that favor hydrolysis degradation. In this way, the relative percentage of crystalline regions increases as a function of the exposure time to degradation in simulated soil. 
Table 1. Crystallization time $\left(\mathrm{t}_{\mathrm{cc}}\right)$ and crystallinity index $\left(\mathrm{X}_{\mathrm{c}}\right)$ of the PLA, E-PLA/ENDO and E-PLA/EXO samples.

\begin{tabular}{|c|c|c|c|c|}
\hline Sample & $\begin{array}{l}\text { Ts } \\
\left({ }^{\circ} \mathbf{C}\right)\end{array}$ & $\begin{array}{c}\text { Te } \\
\left({ }^{\circ} \mathbf{C}\right)\end{array}$ & $\begin{array}{c}\mathbf{t}_{\mathrm{cc}} \\
(\mathrm{min})\end{array}$ & $\begin{array}{c}X_{c} \\
(\%)\end{array}$ \\
\hline PLA & 110.70 & 143.45 & 3.27 & 23.99 \\
\hline E-PLA/ENDO & 115.78 & 144.39 & 2.86 & 28.79 \\
\hline E-PLA/EXO & 97.54 & 109.19 & 1.16 & 36.75 \\
\hline
\end{tabular}

Ts - Temperature onset and $\mathrm{Te}-$ Temperature endset.

Table 2. Thermal characterization temperatures and crystallinity index for neat PLA and E- PLA/EXO and E-PLA/ENDO samples by DSC.

\begin{tabular}{lccccc}
\hline \multicolumn{1}{c}{ Sample } & $\begin{array}{c}\mathbf{T}_{\mathrm{g}} \\
\left({ }^{\circ} \mathbf{C}\right)\end{array}$ & $\begin{array}{c}\mathbf{T}_{\mathrm{cc}} \\
\left({ }^{\circ} \mathbf{C}\right)\end{array}$ & $\begin{array}{c}\mathbf{T}_{\mathbf{m}} \\
\left({ }^{\circ} \mathbf{C}\right)\end{array}$ & $\begin{array}{c}\Delta \boldsymbol{H m} \\
(\mathbf{J} / \mathbf{g})\end{array}$ & $\begin{array}{c}\mathbf{X}_{\mathbf{c}} \\
(\boldsymbol{\%})\end{array}$ \\
\hline PLA 0d & 61.89 & 123.58 & 154.77 & 22.48 & 23.99 \\
PLA 30d & 58.75 & 98.56 & 154.90 & 26.11 & 27.86 \\
PLA 60d & 57.40 & 108.40 & 154.96 & 24.38 & 26.01 \\
PLA 90d & 57.45 & 102.18 & 155.27 & 28.88 & 30.82 \\
E-PLA/ENDO 0d & 58.22 & 115.78 & 154.34 & 26,98 & 28.79 \\
E-PLA/ENDO 30d & 58.86 & 115.12 & 155.36 & 28.34 & 30.24 \\
E-PLA/ENDO 60d & 59.06 & 116.71 & 154.33 & 28.24 & 30.13 \\
E-PLA/ENDO 90d & 58.27 & 107.85 & 156.40 & 20.96 & 22.36 \\
E-PLA/EXO 0d & 56.08 & 103.0 & 154.70 & 34.44 & 36.75 \\
E-PLA/EXO 30d & 47.30 & - & 149.68 & 32.98 & 35.19 \\
E-PLA/EXO 60d & 56.14 & 102.42 & 154.02 & 32.01 & 34.16 \\
E-PLA/EXO 90d & 53.60 & 89.65 & 150.76 & 29.22 & 31.18 \\
\hline
\end{tabular}

The increased crystallinity in PLA is also associated with the hydrolytic scission and consequent formation of lower molecular mass polymer chains, which can rearrange to form new crystals ${ }^{19,23-25}$.

For the E-PLA/ENDO and E-PLA/EXO samples, the crystallinity percentage decreased during exposure to the degradation environment. This result likely occurred because of chain scission of chains during exposure. This result corroborates with the decrease of the mechanical properties of the E-EVA samples. The crystallinity percentage decrease reduces the compact packing of aligned polymer chains. The polymer chains interact via various types of the van der Waals forces, and the interaction strength depends on the distance between the parallel chain segments. With fewer crystalline regions, the strength of interaction between the chains is smaller, and it is one of determining factor for the mechanical properties of the polymer sample.

\section{Conclusions}

Blowing agents with different decomposition rates directly influence the morphology and mechanical properties of PLA foams. Smaller and more numerous cells were

\section{References}

1. Carvalho G and Frollini E. Lignina em espumas fenólicas. Polímeros. 1999; 1:66-75. http://dx.doi.org/10.1590/S010414281999000100009

2. Rabello M. Aditivação de Polímeros. Artliber Eds; 2001. chapt. 11.

3. Zweifel H, Maier RD and Schiller M. Plastics Additives Handbook. Hanser Publications; 2008. v. 6, chapt. 13, p. 719-744. observed in samples processed with an exothermic blowing agent (E-PLA/EXO), and larger, less numerous cells were observed in the sample obtained with an endothermic blowing agent (E-PLA/ENDO).

With regard to the flexural strength mechanical properties, the E-PLA/ENDO sample showed superior results compared to the E-PLA/EXO sample. Both samples gradually lost their mechanical and modulus properties during exposure to model soil.

In the DSC analysis, Tg and Tcc decreased when lower molecular mass oligomers formed as a result of polymer chain scission caused by degradation. The variation in crystallinity proved that the degradation reached the neat PLA amorphous phase and in the case of the expanded samples, reached the crystalline phase.

The PLA foams that contained chemical blowing agents degraded during exposure to simulated soil. This degradation was revealed by increased hydrolysis that was the result of water infiltration associated with cells. In addition, this phenomenon was observed by FTIR where the increase in the intensity of the band at $3500 \mathrm{~cm}^{-1}$ was ascribed to the hydroxyl group $(\mathrm{OH})$.

4. Throne JL. Thermoplastic Foam Extrusion, An Introduction. Hanser Publications; 2004. v. 1, chapt. 2-3, p. 9-3 7.

5. Gautam R, Bassi AS and Yanful EK. A review of biodegradation of synthetic plastic and foams. Applied Biochemistry and Biotechnology. 2007; 141:85-108. http://dx.doi.org/10.1007/ s12010-007-9212-6

6. Iovino R, Zullo R, Rao MA, Cassar L and Gianfreda L. Biodegradation of poly(lactic acid)/starch/coir biocomposites 
under controlled composting conditions Polymer Degradation and Stability. 2008; 93:147-157. http://dx.doi.org/10.1016/j. polymdegradstab.2007.10.011

7. Oksman K, Skrifvars M and Selin J-F. Natural fibres as reinforcement in polylactic acid (PLA) composites. Composites Science and Technology. 2003; 63:1317-1324. http://dx.doi. org/10.1016/S0266-3538(03)00103-9

8. Wang Y, Tong B, Hou S, Li M and Shen C. Transcrystallization behavior at the poly(lactic acid)/sisal fibre biocomposite interface. Composites: Part A. 2011; 42:66-74. http://dx.doi. org/10.1016/j.compositesa.2010.10.006

9. Lee S-H and Wang S. Biodegradable polymers/bamboo fiber biocomposite with bio-based coupling agent. Composites: Part A. 2005; 37:80-91. http://dx.doi.org/10.1016/j. compositesa.2005.04.015

10. Lim L-T, Auras R and Rubino M. Processing technologies for poly(lactic acid). Progress in Polymer Science. 2008; 33:820852. http://dx.doi.org/10.1016/j.progpolymsci.2008.05.004

11. Ferreira BMP, Zavaglia CAC and Duek EAR. Films of Poly (L - Lactic Acid) / Poly(Hydroxybutyrate-coHydroxyvalerate) Blends:In vitro Degradation. Materials Research. 2001; 4(1):34-32. http://dx.doi.org/10.1590/S151614392001000100008

12. Jain S, Goossens H, Duin MV and Lemstra P. Effect of in situ prepared silica nano-particles on non-isothermal crystallization of polypropylene. Polymer. 2005; 46:8805-8818. http://dx.doi. org/10.1016/j.polymer.2004.12.062

13. Mathew AP, Oksman K and Sain M. Mechanical properties of biodegradable composites from poly lactic acid (PLA) and microcrystalline cellulose (MCC). Journal of Applied Polymer Science. 2005; 97:2014-2025. http://dx.doi.org/10.1002/ app. 21779

14. Bledzki AK and Faruk O. Injection moulded microcellular wood fibre-polypropylene composites. Composites: Part A. 2006; 37:1358-1367. http://dx.doi.org/10.1016/j. compositesa.2005.08.010

15. Tatibouët J, Gendron R and Haïder L. Ultrasonic characterization performed during chemical foaming of cross-linked polyolefins. Polymer Testing. 2004; 23:125-130. http://dx.doi.org/10.1016/ S0142-9418(03)00070-9

16. Cheung H-Y, Lau K-T, Pow Y-F, Zhao Y-Q and Hui D. Biodegradation of a silkworm silk/PLA composite.
Composites: Part B. 2009; 41:223-228. http://dx.doi. org/10.1016/j.compositesb.2009.09.004

17. Pushpadass H, Wever RW, Dumais JJ and Hanna MA. Biodegradation characteristics of starch-polystyrene loose-fill foams in a composting medium. Bioresource Technology. 2010; 101:7258-7264. http://dx.doi.org/10.1016/j. biortech.2010.04.039

18. Lucas N, Bienaime C, Belloy C, Queneudec M, Silvestre F and Saucedo JEN. Polymer Degradation. Mechanisms and estimation techniques. Chemosphere. 2008; 73:429-442. http:// dx.doi.org/10.1016/j.chemosphere.2008.06.064

19. Fukushima K, Abbate C, Tabuani D, Gennari M and Camino G. Biodegradation of poly(lactic acid) and its nanocomposites. Polymer Degradation and Stability. 2009; 94:1646-1655. http:/ dx.doi.org/10.1016/j.polymdegradstab.2009.07.001

20. Shin BY, Jang SH and Kim BS. Thermal, morphological, and mechanical properties of biobased and biodegradable blends of poly(lactic acid) and chemically modified thermoplastic starch. Polymer Engineering and Science. 2011; 51:826-834. http://dx.doi.org/10.1002/pen.21896

21. Drumond WS and Wang SH. Síntese e caracterização do copolímero poli (ácido lático-b-glicol etilênico). Polímeros. 2004; 14:74-79. http://dx.doi.org/10.1590/S010414282004000200009

22. Qin L, Qiu J, Liu M, Ding S, Shao L, Lü S et al. Mechanical and thermal properties of poly(lactic acid) composites with rice straw fiber modified by poly(butyl acrylate). Chemical Engineering Journal. 2011; 166:772-778. http://dx.doi. org/10.1016/j.cej.2010.11.039

23. Rosa DS, Pantano R Fo. Biodegradação - Um ensaio com polímeros. Ed. Universitária São Francisco e Ed. Moara; 2003.

24. Vanin M, Santana CC, Torriani IL, Privelic T and Duek EAR. Estudo da degradação "in vitro" de blendas de poli( $\beta$ hidroxibutirato) (PHB) / poli(L-ácido latico) (PLLA) na forma de filmes. Polímeros. 2004; 14(3):187-193. http://dx.doi. org/10.1590/S0104-14282004000300015

25. Magon A and Pyda M. Study of crystalline and amorphous phases of biodegradable poly(lactic acid) by advanced thermal analysis. Polymer. 2009; 50:3967-3973. http://dx.doi. org/10.1016/j.polymer.2009.06.052 